\title{
5.1
}

\section{The basic constitutional law}

The foundations of any liberal democracy lie with its constitutional arrangements, the key means by which the powers of the state are specified, distributed across different institutions and regulated. Constitutions set out how the state is structured, what its major institutions are, and what basic principles govern their relations with each other and with citizens. In the UK these provisions are famously diverse and uncodified, with no single written 'constitution' document. Michael Gordon looks at how to assess the democratic basis of constitutional law, and how well recent experience suggests that the UK has been performing.

\section{What would a democratic basic constitutional law look like?}

A democratic basic constitutional law should meet a number of formal and substantive requirements.

\section{Formal democratic requirements}

The rules of the constitution need to be - so far as possible - clear, accessible to and understandable for citizens, politicians and officials.

$\downarrow$ Some ambiguities or disputes about these rules are inevitable. Some generally accepted processes (both legal and political) are needed through which issues can be settled in inclusive and transparent ways.

There must be a genuine possibility of the rules changing to enhance the democratic quality of the constitutional system. Processes for constitutional change should be transparent and underpinned by the democratic agreement of citizens.

\section{Substantive democratic requirements}

The actors allocated governmental power must be democratically chosen and removable, with effective processes of accountability for the exercise of constitutional authority - both political, to ensure responsibility for official action, and legal, to ensure the legality of official action.

A variety of institutions will exercise a range of overlapping functions - including those of a legislative, executive and judicial nature. But institutions with democratic legitimacy must be allocated the ultimate responsibility for crucial decisions. 
Opportunities for citizens to engage with and influence those in power must exist. A range of channels should be established. And civil liberties, which allow people to engage in individual and collective political activity, must be ensured.

$\downarrow$ There must be recognition and accommodation of different democratic desires in different parts of the state, with devolution or decentralisation of power so that decisions can be taken at the most appropriate levels of government.

\section{Recent developments}

The basic constitutional law of the UK is in the midst of a period of fundamental change. Perhaps this has been the case for over 20 years, since the election of the New Labour government in May 1997, which began an unprecedented era of constitutional reform. But the electorate's decision to exit the European Union at the June 2016 referendum, rejecting the pro-Remain position adopted by the largest groups inside the UK's three main political parties, will see a further transformation of constitutional law in the UK.

For 43 years the UK constitution adapted to accommodate membership of the EU, and the obligations which that imposes. Now Brexit will see domestic constitutional law reshaped to reverse many of these changes. The future supremacy of EU law over domestic law will be removed on exit day by the European Union (Withdrawal) Act 2018. And we will very likely see the return of law-making competence from the European Union institutions to the UK Parliament, and (subject to some controversial centralising by Westminster) to the devolved legislatures in Scotland, Northern Ireland and Wales. Depending on the nature of any future relationship agreed with the $\mathrm{EU}$, and the obligations that may flow from a possible free trade agreement, this may include the reacquisition of authority in areas including agriculture, fisheries, consumer rights, workers' rights, product standards, competition, public procurement, immigration and trade.

This will be a significant change to the constitutional authority of the domestic institutions, which had previously opted to combine their decision-making power with that of other member states in a process of EU-wide cooperative law-making. But it will also represent a major challenge for the UK constitution, as the institutions of government attempt to deal with this unprecedented shift, across multiple strands of activity. There is the legislative challenge of preparing the UK for the withdrawal of EU law; the diplomatic challenge of negotiating exit and potentially a new relationship; the policy challenge of making effective decisions in areas of reacquired competence; and the scrutiny challenge for Parliament and the courts in ensuring that all of this is done in a legitimate manner.

Yet Brexit is just one of a number of high-profile constitutional developments in recent years with potentially far-reaching implications. These include an independence referendum in Scotland in 2014, a national general election in 2015, the EU referendum in 2016, and a further general election in 2017. The UK constitution is facilitating repeated high-level democratic exercises - some easily anticipated, like the 2015 election, others less so, like Theresa May's snap 2017 election. In different ways, the two referenda might perhaps be viewed as inevitable, given the political environments cultivated by successive UK and Scottish governments, both from positions of weakness and strength. 
This political turmoil has also left the UK constitution exposed to very rapid change. While Scotland voted to stay within the UK, the 2014 referendum did prompt further farreaching devolution of powers to Edinburgh. It also raised expectations in other devolved governments, leading to further devolution for Wales and Northern Ireland (although the Northern Ireland Assembly and Executive both remain suspended through most of 2017 and 2018, which left a major constitutional and democratic vacuum at a significant time). The 2015 election created the conditions for the 2016 referendum, which led to the end of one government, the formation of another, and in less than a year a further general election. The major changes that will flow from Brexit have also therefore been complicated further by the hung parliament which resulted from the 2017 election, and the uncertain authority of Theresa May as Prime Minister.

We might therefore have reached (or passed) the point of constitutional fatigue - with radical change occurring at an intense pace both to the rules of the constitution, and to the position and authority of those allocated constitutional powers. And while fatigue may be setting in, the pace of change is only likely to accelerate, with new constitutional challenges resulting from the reshaping of the UK which is underway. For example, Brexit has great potential to trigger further change to the union, as calls are made for a second independence referendum in Scotland, or a border poll on the reunification of Northern Ireland with the Republic. The confidence and supply deal negotiated by the Conservatives with the DUP to sustain the minority Tory government in office has the potential to destabilise efforts to restore devolved government in Northern Ireland, with a return to direct rule from Westminster for a considerable period a serious prospect. Given the instability of the present government, a further election before 2022 (the legally due date) also looks more likely than not.

\section{The Supreme Court}

While the UK's constitutional politics have reached a level of almost peak unpredictability, there has been a less obvious, gradual shift in the position of the courts. The expansion of judicial powers made necessary by EU membership were supplemented considerably under the Human Rights Act 1998 - which gave the judiciary new powers and duties to assess the compatibility of official acts with human rights. In the 21st century this has been accompanied by the development of a striking constitutional self-confidence amongst judges. The most senior judges were relocated from the archaic Appellate Committee of the House of Lords to a new Supreme Court, by the Constitutional Reform Act 2005. On the face of it, this did little to change the pre-existing substantive independence of the judges. But this significant 'rebranding' exercise has profoundly reinforced the judges' willingness to engage with constitutional questions in bolder ways.

The Supreme Court has recently begun exploring common law constitutional frameworks in novel ways (HS2), challenging the otherwise clear language of statutory provisions (Evans), and gesturing at the possibility of exceptional limitations on the UK Parliament's sovereign law-making power (Moohan). The peak of the judges' new prominence was the Miller case, on the constitutional requirements for commencing withdrawal from the EU. There was a furious academic and public debate about how this could be done, as these legal issues 
were considered in the High Courts of England and Wales, and Northern Ireland, before progressing to the Supreme Court. By a majority of eight Justices to three, the Supreme Court held that a new Act of Parliament was required to authorise the Prime Minister giving notice of the UK's intention to leave the European Union. This was an affirmation of the decision of the High Court of England and Wales, albeit on somewhat different grounds, based ultimately on the premise that Brexit would cause a change to the legal sources of the constitution of such magnitude that it could not be commenced by the government using its royal prerogative powers to conduct international affairs. The majority decision by the Court might be criticised as being high on constitutional principle, but lacking in rigorous interpretation of the relevant statute establishing the status of EU law within the UK, or sensitivity to the broader political framework allocating different institutional responsibilities. Yet even aside from the major results of these cases, the shift in judicial power is both a complex and important phenomenon. It raises fundamental questions about the changing role of non-democratic actors in the UK's constitutional system, especially within a period of extraordinary realignment.

\section{Strengths, Weaknesses, Opportunities, Threats (SWOT) analysis}

\section{Current strengths}

The 'manner and form' theory of parliamentary sovereignty holds that the UK Parliament possesses a legislative authority that is not legally limited. It can pass laws with any content that it chooses. And it can also change its own legislative procedures in any way it chooses.

This provides a secure basis for a strong executive government, founded on a democratic responsiveness to the wishes of a majority of voters, and subject to political accountability in the UK Parliament. It also ensures there are few formal barriers to radical (democratic) constitutional reform.

\section{Current weaknesses}

Alternative accounts of how the UK's basic constitutional set-up now works allocate a larger role to the Supreme Court and judges in regulating how the core institutions of the state operate. On the 'common law constitutionalist' theory, 'the UK's constitution is higher law made by the conscious decisions of a legislature to create principles of fundamental significance'. This view may lie behind the Supreme Court's January 2017 decision that because Brexit entails changes in legal sources and rights, it requires an explicit Act of Parliament to start that process - and could not be done under the executive powers to make and unmake treaties, as initially claimed by the May government.

Yet this may be part of a shift from the UK's 'political constitution', in which the constitutional constraints on a UK executive with a Commons majority primarily flow from politics. Such limits are less formal, more fluid, and their effectiveness is hotly disputed - but it is far from clear whether a move to greater constitutional limitation through legalism will produce better democratic government. 


\section{Current strengths}

The era of reform to the UK's constitutional law started by New Labour in 1997 has had generally positive results. Those changes have either been extended, as is the case with the further devolution of powers to democratic institutions in Scotland, Wales and Northern Ireland, or proved resilient to retrenchment, for example, the Freedom of Information Act 2000.

Frequent opportunities exist for the electorate to freely express their will, both in parliamentary elections and referenda, and for citizens to shape the policy agenda, such as via the parliamentary petitions website.

\section{Current weaknesses}

Despite the era of reform, non-democratic institutions remain, and wield considerable power. The House of Lords is only partially reformed and still unelected, yet it is increasingly relied on as a check on government and the House of Commons.

Public debate about the monarchy is absent, even though the Queen has been ever more insulated from key political decisions - such as that relating to the formation of a government in a hung parliament by the codification of rules in the Cabinet Manual.

The rapid extension of devolution has also posed challenges - notably the pace of change in Scotland; difficulties achieving consensus in Wales over the new reserved powers Act of 2017; continuing problems in establishing a government in Northern Ireland; and some inconsistencies in the Combined Authority deals in England. There has been a lack of transparency or citizen engagement in the process.

Moreover, establishing English votes for English laws in the Westminster Parliament may initially have seem an underwhelming change, but it could yet have consequences for the equality of MPs. And a failure to obtain the consent of the Scottish Parliament for the European Union (Withdrawal) Act 2018 raises concerns about the authority of the democratic principles and conventions underpinning the structures of devolution. 


\section{Current strengths Current weaknesses \\ Only limited critical or considered debate has taken place about the recent increasing prominence of the courts, especially given longstanding concerns about the total lack of ethnic diversity and dramatic under- representation of women among the senior judiciary. Also important are the increasing powers over moral-political issues that judges now exercise as a result of the Human Rights Act 1998, without being subject themselves to regular accountability processes. Human rights litigation has also produced some frustrating, fragmented, and inaccessible judgments on major issues, for example on assisted dying (Nicklinson) and abortion rights (NIHRC).}

\section{Future opportunities}

Further strengthening and broadening of devolution across the UK may be achievable. Continuing decentralisation of aspects of decision-making can create and reinforce new sites of democratic activity to challenge and compete with the Westminster institutions. (However, there are also real concerns about the democratic engagement of citizens in the process of deciding what to devolve.)

\section{Future threats}

The scale of the Brexit process will test the capacity of the UK's political institutions to the limit. There will be a strong need to ensure the Westminster government is held to account for the array of decisions it will take as it becomes paramount. The allencompassing nature of withdrawal from the EU will leave little time for any other democratic reform. Yet it may also represent a complacency about the superiority of UK's exceptional constitution that should be challenged and dispelled. 


\section{Future opportunities}

The inadequacy of the first-past-the-post voting system for elections to the Commons is increasingly clear. It has difficulties in accommodating an increasingly plural approach to politics, and recently has also failed to achieve its supposed purpose of delivering decisive election results. The return to a hung parliament after the 2017 election may present a further opportunity for critics to press the case for reform to the voting system, to establish a system of proportional representation.

The lack of social diversity amongst judges has gone beyond the point of being indefensible. The appointment of a new Lord Chief Justice in 2017 offered little hope in this regard. However, Lady Hale is now the President of the Supreme Court, and she has been joined by two further female Justices. Yet formal quotas would still be required to alter substantially the dynamics of judicial appointments, and accelerate current glacial progress.

\section{Future threats}

The result of the Brexit referendum, and its potentially damaging consequences, may have a chilling effect on the use of direct democratic decision-making, or engagement with other kinds of democratic innovation in future. If Brexit has poor consequences, the lesson drawn may be to stick to conventional representative government only.

Rather than reverting to such pure representative democratic systems, ways of deepening the electorate's involvement in democratic methods of reform should be further explored, such as via a constitutional convention or citizens' assemblies.

Any debate about codification of the UK constitution, or establishing a formal legal federal order in the aftermath of Brexit, is likely to be a distraction. Its democratic salience is also disputable. A legalised constitution is not necessarily democratically superior to an ('unwritten') political constitution, especially when there is much to seek to reform, rather than to entrench, in the UK's present arrangements.

\section{Brexit}

Brexit will dominate constitutional discussions during (and well beyond) the process of exiting the EU, running to 29 March, 2019. Parliament needs to ensure that democratic scrutiny and accountability is as effective as possible during this period of unprecedented change. The European Union (Withdrawal) Act 2018 (albeit necessarily) delegates a great deal of subordinate law-making authority to the government. But this delegation needs to be subject to strict and appropriate limits on the use of the powers. Thorough and detailed parliamentary scrutiny will be needed to ensure their exercise does not instigate major changes in legal regulation for which a democratic mandate has not been obtained. A new parliamentary review process has been designed to sift through the estimated 8001,000 subordinate laws which may need to be enacted. A Commons European Statutory Instruments Committee will examine all proposed secondary legislation in preparation for Brexit, and flag those that ought to be subject to debate and the positive approval of Parliament.

The 2016 referendum result may provide the government with a mandate to deliver the UK's exit from the EU. However, if the process and its results are to be regarded as 
legitimate, then the nature of that exit, and the means by which it is achieved, will have to be negotiated in a constructive, transparent way in a much more complex democratic landscape. As a matter of political principle and constitutional convention, if not by law, the interactions between the UK institutions and the devolved legislatures and governments are crucial to this. The consent of the Scottish Parliament, Northern Ireland Assembly and National Assembly for Wales should have been required to make legislative changes to the devolution statutes and competences. Yet only the Welsh Assembly gave its approval to the European Union (Withdrawal) Act 2018. The UK government pressed ahead without consent from the Scottish Parliament, raising serious concerns about the extent to which democratic principles underpinning devolution are being respected, and bolstering calls for a second independence referendum in Scotland. Political and statutory commitments have been made to ensure the UK Parliament gets a 'meaningful vote' to approve a Withdrawal Agreement negotiated by the government, and any deal will be for Parliament to implement through new primary legislation. Parliament has also legislated to require the government to report on progress if 'no deal' becomes a likely outcome, providing an avenue for this to be challenged in the legislature.

\section{The nature, extent and process of constitutional change}

Away from the immediate challenge of Brexit, the impact of the dramatic programme of constitutional reform commenced by New Labour in 1997, but continued by the 2010-2015 coalition government, and the Cameron government after the 2015 election, is still to be assessed. The pace and scale of change has been rapid, and hard to keep up with suggesting that we must also try to take stock to establish future priorities.

It is not a straightforward question to answer 'where is the UK constitution now?' because the constitution is still changing, and further change is to come. Nevertheless, there remain particularly important questions to consider concerning the manner in which we have changed the law of the constitution. New Labour believed in 'constitutional modernisation', but had no overarching vision of what that meant in order to structure the reform programme it actually carried out. This may explain why a systematic approach has subsequently proved elusive. What New Labour produced is a constitution that we can think about holistically and explicitly, and be prepared to change in a proactive way. But if the goal of 'modernisation' simply becomes an end in itself, rather than directed to achieving other values, we can end up (and perhaps, to some extent, have ended up) lacking the ability to work out exactly what has been successful, and where further efforts must be targeted. A structured, value-oriented approach is important to constitutional reform - that may be the key lesson to emerge from the changes of the last two decades. We must at least attempt to sketch some kind of coherent vision of the overall constitution that we ultimately want for the UK. In so doing, we can try to develop a clearer sense of how we can make the constitutional law of the UK more democratic, both in substance and in its processes. 


\section{A vision for a democratic UK constitution?}

The UK constitution is at a crossroads - partially reformed, but with further change imminent. The process of reform - through the abundance of new statute law, and written constitutional documents - has made the constitution more formalised. Yet the UK's arrangements are still fluid, and stand far apart from a traditional codified constitution. For some observers this may be a democratic deficiency. As the UK political system has become more overtly 'constitutionalised', calls have increased for a codified, written constitution to be established. This could more clearly define, and also limit, the powers of Parliament and the government. Such a model could more firmly federalise the powers of the devolved institutions in Scotland, Wales and Northern Ireland. The increased accessibility of such a constitution may appear attractive. Yet a decisive shift from a political to a legalised constitution would also have many costs. It would likely entrench inadequate existing arrangements, create potential barriers to further reform, along with accomplishing the (further and greater) empowerment of the judiciary, who would be tasked with enforcing its rules in increasingly contentious political circumstances.

The crucial (and enduring) idea of parliamentary sovereignty at the heart of the UK constitution can (rightly) attract criticism if it is used as a rhetorical device signalling the centrality of Westminster politics, or the international superiority of the UK. Yet it is a fundamentally democratic foundational principle of UK constitutional law, in allocating ultimate law-making power to the elected and accountable actors in the UK's system of government. Rather than displacing parliamentary sovereignty by pursuing the distraction of codifying the UK constitution, a better vision for democratic constitutional change involves exploiting that unlimited legislative authority to complete substantive institutional reform: to the House of Lords, the voting system, the monarchy and the royal prerogative powers, the funding and election spending of political parties, voter registration and age limits, the ownership of the media, among others.

Such an orientation would be accompanied by consideration of the process and methodology of constitutional reform, and its democratic components. How can we use democratic instruments more effectively and constructively, and deepen levels of citizen engagement and deliberation? Can we regularise and enhance the use of direct democracy (like referenda), which is at present irregular and under-informed, so therefore potentially erratic? Being aware of the limits of 'the constitutional' means recognising that effective citizen engagement is a function of political culture and education, as much as it is a product of any particular legal institutional arrangements.

Yet the engagement of the people in reshaping the basic constitutional law of the UK is something of intrinsic democratic importance, while also crucial in the present age of political distrust and citizen alienation. Further democratising the constitutional law of the UK - both in substance and in terms of the process of reform - is no doubt a goal that poses great difficulties, both in general and especially in the age of Brexit. Yet greater difficulties would be caused by allowing this era of democratic change to stall at a point where much more remains to be done.

Michael Gordon is Professor of Constitutional Law at the University of Liverpool. 